\title{
Adoption and Infanticide in Edward Albee's The American Dream
}

\author{
Ms Ramandeep Mahal \\ Research Scholar in English, Department of Humanities and Social Sciences, Maharishi Markandeshwar \\ University, Mullana (Ambala)
}

\begin{abstract}
The play The American Dream presents a useless existence of an individual in the world. None of the characters in the play are considered to be normal. Their seeking for perfection leads to a crime. A crime that was hidden for many years and Grandma eventually discloses it to an outsider. Mommy represents the typical selfish individual who is concerned more about her needs. Daddy is only a mere puppet in the hands of Mommy. His repeated dialogues convey the audience about his abnormality. As Mommy and Daddy are unable to conceive, they plan to adopt a child. The child is unable to meet up to their expectations so they castrate it and eventually kill it, hence committing an infanticide. Ironically the child is compared to a consumer product that is discarded when it leaves the consumer unsatisfied. Albee has attacked the American society and its values. At the end of the play a young man comes into the family to replace the previous child. This young man seems to be a personification of the American Dream that every individual desires for.
\end{abstract}

Keywords: crime, infanticide, American Dream, consumer.

The American Dream tries to make an attempt to present a cynical expression of repulsion against false American optimism. Albee has taken over the responsibility to write a play that throws away the false virtues and vices of the American culture and at the same time familiar with the fall of that culture. The play can be seen as a close inspection of the circumstances of the modern man on both sides of the Atlantic. The archetype of the American family is criticized by exposing the materialistic values that replaced the original ones. An observance made in the play is the stock names used in it, Daddy, Mommy and Grandma. It makes one feel universal, being attached to these names; everyone has a Daddy, Mommy and Grandma. Moreover, these names are short of any personal intensity because they are plain caricatures of a black comedy, which is a usual characteristic of the Absurd Theatre.

Albee has been controversial for his denouncement of American values and for his unwavering commitment to produce higher art. He believed in firstly trying to make a statement about the condition of man and secondly a statement about the nature of art form he was working with and in both these making a change.

A useless existence in life is where an individual lives or suffers memory lapses and inborn paralysis that can never be corresponded through proper speech. The portrayal of such a condition is the main concern of any playwright who belongs to Samuel Beckett's realm. Hence, criticism of a particular society is not the aim of any Absurdist whereas in a play like The American Dream the audience is already set to watch an American drama; the dramatist attacks a society in its very basic unit, the family. Many critics considered the play as a representative of the Absurd Drama; Nicholas Canaday in Albee's American Dream and Existential Vacuum labeled, "The American Dream as America's best example of what has come to be known as 'the theatre of the absurd"'(28) Damien Jaques in A Discussion of Modern American Drama: Edward Albee refers to the play as the starting point of the Absurd Theatre in America, he writes saying that, "Don't let The American Dream as the beginning of the American absurdist theatre movement frighten you." (11)

During the two global wars, The United States of America witnessed astonishing changes in all the wakes of life. When American life changed from an agricultural suburban society to a modernized one, the generations that came afterwards gradually started to develop a delicate psychological state of nostalgic belonging to the virgin land of America, which was according to Robert. E .Spiller in An Introduction to American Literature, "experiencing swift growth and change" as a result of a changing economy, society and culture, because of the influx in the number of the immigrants into America." (269)

The new consciousness the First World War brought at large was to influence the American moral and intellectual values. The American individuality was first threatened by the advent of machines and the creation of the urban societies where everything becomes identical, materialistic ambition and social distinction. The war worsened the situation as people started to feel that every individual's destiny is something impersonal. The sense of revolt in America was originally based on a desire of reconstructing the ruins of the modern disintegrated society. Spiller states: 
The World War broke down America's most fundamental institutions by dehumanizing the people that provided their strong foundations. War diminished the individual identity and the society as a whole. The human personality was "dwarfed" as much by the dehumanizing magnitude of modern events. (303)

Mommy and Daddy live in an urban modernized department, which Albee chose to present his archetypal couple. All the things in that apartment, as Mommy protests needs to be fixed, "the icebox ... the doorbell ... try to get the leak in the Johnny fixed!"(58)

The commencement of the play foretells a physical depravity that society experiences. The surroundings in which Mommy and Daddy live are already worsening which implies an imminent collapse at a deeper level. Practically, the matchbox apartments of a society are usually designed to look alike; identical to one other, they form one symmetrical, yet a dreary structure. With such a substantial amount of likeness, the end of a certain level of individuality is predictable. The loss of personal dimensionality simply begins with an inhuman process of uniting all the close details that discriminate the geographical aspects of human life.

Albee stresses on examining the life of an American married couple, Daddy and Mommy, to be an epitome for that nation. The post war American generation generated a defeatist culture characterized by the desolate and miserable background, passing through the same materialistic persuasion and besieged to the soul by the psychologically infertility of that age. Additionally the story of the American family goes back to the time when there were different concerns determining the individuality of a genuine life, those families lead on the fertile land of America. Furthermore, withdrawing the modern family from fitting in a larger society, due to the feeling of displacement, its members could not look for any reconciliation outside their little apartment. They feel secluded from their society and a deeper dismemberment of their own family.

Child murder is brought in the plot by a means of an exhibition as S. Barnett in A Short Guide to Writing about Literature remarks "that part which tells the audience what it has to know about the past, the antecedent action.'(95), in which Grandma and Mrs. Barker are discussing about an event in the past. Mrs. Barker, the visitor, pays no attention to the reason why she has been called to that house and asks Grandma, who in turn, starts recalling the supposedly true story of a child murder. And she begins recounting the event in the same way as children are told stories by their elders, "Once upon a time, not very long ago . ."(96) suggesting that all that is to be told is a fable or some kind of unrealistic game which Grandma, Mommy and Daddy consequently have fashioned to gratify their need of becoming a proper family. But since Mommy and Daddy are unable to have any children of their own; they decide to make their dream visible and adopt a child. Unfortunately this child becomes a nightmare for them in the sense that the child's outlook and approach is considered so awkward that they incarcerate it and then give it a brutal death. Gradually in a meticulous way, Grandma depicts the way the "bumble" is murdered after having its parts torn away. Mrs. Barker is considered a part of this brutal world for she looks forward to all the grotesque acts being done to the child.

GRANDMA: But that was only the beginning. Then it turned out it only had eyes for its Daddy.

MRS. BARKER: For its Daddy! Why, any self-respecting woman would have gouged those eyes right out of its head.

GRANDMA: Well, she did. That's what she did. (99)

After the eradication of the boy's eyes, the parents move to further monstrous acts with no conceivable reason behind it. Eventually they move ahead and castrate the child.

GRANDMA: That's what they thought. But then, it began to develop an interest in its you-know-what.

MRS. BARKER: In its you-know-what! Well! I hope they cut its hands off at the wrists!

GRANDMA: Well, yes, they did that eventually. But first, they cut off its youknow-what.

MRS. BARKER: A much better idea!

GRANDMA: That's what they thought. But after they cut off its you-know-what, it still put its hands under the covers, looking for its you knowwhat. So, finally, they had to cut off its hands at the wrists.

MRS. BARKER: Naturally!

GRANDMA: And it was such a resentful bumble. Why one day it called its Mommy a dirty name.

MRS. BARKER: Well, I hope they cut its tongue out!

GRANDMA: Of course. And then, as it got bigger, they found out all sorts of terrible things about it, like: it didn't have a head on its shoulders, it had no guts, it was spineless, its feet were made of clay . . . just dreadful things.

MRS. BARKER: Dreadful. 
GRANDMA: So you can understand how they became discouraged.

MRS. BARKER: I certainly can! And what did they do?

GRANDMA: What did they do? Well, for the last straw, it finally up and died; and you can imagine how that made them feel, their having paid for it, and all. So, they called up the lady who sold them the bumble in the first place and told her to come right over to their apartment. They wanted satisfaction, they wanted their money back. That's what they wanted. (100)

The above in depth description of the "dreamy child's" maiming shows the deteriorating process of a dream, in the similar way as Nina in Eugene O' Neill's Strange Interlude (1928) failed as her dreams of becoming a mother shattered when she aborted the child. Similarly Mommy and Daddy had a dream to have a child who would stand for the ideal American child, a boy who would accomplish their hopes and wishes of being actually "Mommy and Daddy". They wanted to achieve the title "Mommy and Daddy". Sadly this child turns out to be the contrary to the principles the mother and father were expecting from him, so they see mutilation as the only solution until it is reduced to nothing. As opposed to Nina who has to abort the child due to the curse of the insanity in the family, Mommy and Daddy have no tangible reason for killing the child. Simply as the child does not satisfy the parents dream, they feel that it is their fair responsibility to annihilate it.

Thus, as the "Bumble of joy" did not work out, Mommy and Daddy contemplate on calling the lady who sold it to them and ask for a refund. Hence adopting the child does not seem to be anything else than attainment of some kind of material good. Since they are displeased with the child, and that is what they paid for, money is their only concern now.

However, since the beginning of the play there is a hunt for an ideal family life which is both distorted and shattered. This ideal is distorted in the sense that there is a married couple, Mommy and Daddy and a Grandma who lives with them; but in fact, they are only individuals who seek to have an identity of a Grandma, a Mommy and a Daddy. As they lack the ability to have a child who can accomplish the tasks of a mother, father and grandmother, it is destroyed. The reason behind this is that after the adoption of the son, the child does not seem to satisfy the parent's ideal of a son, so they kill it. As Martin Esslin comments in The Theatre of the Absurd, "the American dream fairly and squarely attacks the ideal of progress, optimism, faith in the national mission, and pours scorn on the sentimental ideals of family life, togetherness and physical fitness."(302)

The breakdown of the perfect model family life is also present as there seems to be lack of togetherness or understanding among the members of the family. As for Mommy, she has to force Daddy to pay attention to what she is telling him. He seems to be disinterested even though he tries to exhibit the opposite by reiterating to what she last said-a tendency explored by the Absurd Theatre.

MOMMY: And I said "Oh, it's just lovely." And so I bought it. (Stops, looks at Daddy)

DADDY: (To show he is paying attention) And so you bought it. (59)

The lack of communication between the characters and consequently their misunderstanding forces them to "to create" a human being capable of keeping their dreams alive. They want the son to symbolize the perfection they are seeking for, through an ideal family, but cannot achieve it. Closely associated with the concept of an idealistic family, of an idealistic American dream men, is what W. Guerin in A Handbook of Critical Approaches describes as "the Myth of Edenic Possibilities, which reflects the hope of creating a Paradise, not in the next world and not outside time, but in the bright New World of the American continent. From the time of its first settlement American was seen from European eyes as a land of boundless opportunity, a place where man, after centuries of poverty, misery and corruption could have a second chance to fulfill in reality, his mythic yearnings for a return to Paradise.”(142)

The conversation between Daddy and Mommy is a long matter of clichés and repeated patterns. They do not succeed in communicating at both personal and social levels, a fact that makes them incapable to conquer a subsequent return to the inner self in the form of an extreme selfishness. It seems that Albee himself felt that displacement so strongly that none of his plays surrendered this trait. Brian Way in Edward Albee: A Collection of Critical Essays writes that Albee's, "characters are isolated from each other in little worlds of selfishness, impotence and lovenessless, and all the warmth of human contact is lost."(34)

The motive behind viewing the play as an Absurd piece is the depersonalization of Daddy and Mommy as they turned out to be mere puppets; in this respect, Albee imitates Beckett in producing the blemished characters. Even language is not able to escape this enforced deformity hence another motive is considered. Taking Mommy and Daddy as examples, Albee intentionally gave them names that are short of personal uniqueness and he, therefore, denied them of their individuality. Throughout the play, we hardly hear them calling each other by original names, nick names or the names of endearment. This is definitely an indication of 
the universality that the modern playwrights try to tinge their drama with. Characters with no names indicate particular dullness that illustrates modern individuality against everything authentic and humanly rich.

Language is a probable way to come near Mommy and Daddy; language develops into a performative device where words generate beyond the linguistic level in which a word does something more than articulating a certain meaning. In the case of The American Dream brutality pertains to language turning it into a metaphorical vehicle of psychological parody acted among both the characters; Mommy and Daddy. Speaking psychologically the abnormal relationship between Mommy and Daddy is one of sadomasochistic nature.

Mommy, the brutal sadistic authoritarian weakens Daddy through practicing independence and control over the house with a harsh and domineering language. Mommy at one time, imposes on Daddy to repeat the story of the hat she had purchased and returned it to change because of its different colour:

MOMMY: I said, well my dear, I know beige from wheat too. What did I say?

What did I just say?

DADDY: (Tonelessly) Well, my dear, I know beige from wheat too. (60)

Daddy is forced unwilling to open the door like any houseboy. He falters to open the door believing it to be the van man who is supposed to take Grandma; Mommy mocks a man shaken personality in her husband:

MOMMY: Open the door.

DADDY: Was I firm about it?

MOMMY: Oh, so firm; so firm.

DADDY: And was I decisive?

MOMMY: SO decisive! I shivered.

DADDY: And masculine? Was I really masculine?

MOMMY: Oh, Daddy, you were so masculine; I shivered and fainted.

GRANDMA: Shivered and fainted, did she. Humf!

MOMMY: You be quiet! (74)

Mrs. Barker turns out to be the visitor on the door and she is attacked by Albee's crowded sentences in spite of the social conventions regarding the guest. Mommy, a woman of social status, symbolizes all the false social respectability:

MOMMY: Would you like a cigarette, and a drink, and would you like to cross your legs? (77)

Daddy, in return converses and acts like an infant a child. He represents an emasculated man. As Mrs. Barker pulls the hem of her slip above her knees, Daddy identifies with what would happen to man, except him, if encountered with such temptation:

DADDY: I just blushed and giggled and went sticky wet! (79)

The central disagreement that grows between Grandma and Mommy is Mommy's endeavor to get rid of Grandma from her life by placing her in a nursing home. This attempt fails due to the natural impulses and liveliness of Grandma. Through this structure, Albee introduces the fall of the American Dream.

When Mrs. Barker arrives, neither Mommy nor Daddy is familiar with her or her work. A debate takes place regarding the purpose of her coming which is related to the packing of Grandma's boxes. A discussion between three of them reveals the contents of the boxes.

Grandma is Mommy's mother who lives with the couple. Throughout the play Mommy and Daddy verbalize with her in a rude manner and treat her in an appalling manner. She is required to do many of the household chores including, "the cooking and the housework, polishing the silver, moving the furniture."(67) In Mommy and Daddy's household, the normal order is inverted. Rather than taking care for Grandma, the progeny anticipate the elderly woman to "earn her keep" (67) and take care of the house. Their wisdom is that everyone in a society or family must be commercially productive has led to turning down in filial duty and respect. Grandma is one character in the play that is unaffected by greed. Lucid and forthright, she observes the moral collapse around her but can find no refuge.

GRANDMA: When you get old, you can't talk to people because people snap at you. When you get so old, people talk to you that way. That's why you become deaf, so you won't be able to hear people talking to you that way. And that's why you go and hide under the covers of the big soft head, so you won't feel the house shaking from people talking to you that way. That's why old people die, eventually. (65)

Shown contempt by Mommy and Daddy, Grandma provides a thematic counterpart to the couple. As Lee Baxandall in The Modern American Theatre: A Collection of Essays writes, "Three generations comprise Albee's archetypal family. Then, the epoch of a still-dynamic national ethic and vision; now, a phase which breaks into several tangents of decay; and nowhere, a darkly prophesied future generation."(81) Grandma is a 
representative of Baxandall's "then" generation; she represents a time before America's descent into consumerism but now must content herself with offering commentary on the current state of affairs.

Grandma is a vaguely drawn character who draws the attention of the audience to gain sympathy for the terrible treatment she receives from everyone despite her honesty. This honesty is recognized by the audience and hence identified with her good nature. Grandma's good nature and her bitter treatment by the people around her reflect the society's way in looking down at her and Mommy's ungrateful treatment to her as a senile woman.

GRANDMA: You don't have any feeling, that's what's wrong with you. Old

people make all sorts of noises, half of them they can't help ...

you should have gotten rid of me a long time ago if that's the way

you feel. (70)

She signifies all the values that are longer applied to the present; leaving home signifies the exodus of innocence, virtue and purity from present culture. Michael E. Rutenberg, Edward Albee: Playwright in Protest writes that:

Grandma represents a time already past, when hard work was society's backbone rather than a drive for money. And in true fashion her children think she doesn't understand things very well anymore because she puts on that act, but in reality she understands more than anyone. (230)

A question arises regarding whether the contents of Grandma's boxes could help showing something connected to her past and hence ascertain the true principles of the past in their original state. Albee purposely appears to puzzle the audience regarding the contents of the boxes and at the same time inquire about their significance by Mommy, Daddy and Mrs. Barker; Michael E. Rutenberg states that, "these 'contents' are, in effect the 'content' of the American drama. Grandma possesses the substance of it all, and leaves only the shell behind, in the form of empty-headed, vicious Mommy and passive, disemboweled Daddy." (231)

The only thing that draws the attention of Mommy and Daddy is how well these boxes are wrapped representing the degree to which these people value the superficially "shell" realities of life.

MOMMY: Look how pretty Grandma wrapped these boxes.

DADDY: I did not really like wrapping them; it hurt my fingers, and it frightened

me. But it had to be done. (71)

Albee tries to present a vague impression to his audience in order to eliminate the instinctive approach to rationalize the character's behavior, in spite of Grandma's refutation of any knowledge of Mrs. Barker. However Mommy shows a strong memory saying, "Yes we are here Grandma. I'm Mrs. Barker. I remember you; don't remember me?" (76) Aware of the van-men's arrival, Grandma is terrified as Mommy and Daddy torment her by referring to Mrs. Barker as if Mrs. Barker is also scheming against Grandma.

MOMMY: Speak to them Grandma.

GRANDMA: I don't see them.

DADDY: For shame, Grandma, they are here.

MRS. BARKER: Yes, we are here, I am Mrs. Barker. (76)

As Mrs. Barker announces herself as the chairman of the Mommy's women's club, Mommy fails to identify her; it appears that some repression or a certain dilemma has left a puncture in Mommy's memory, causing a short-lived memory lapse. After the visit of Mrs. Barker the e defective memory of the family is exposed. Daddy fails to memorize her name twice just few minutes after her introduction:

DADDY: Pardon me, What is that name again?

MRS. BARKER: Mrs. Barker.

DADDY: Exactly, what does it have to do with why ... that name again? MRS. BARKER: Mrs. Barker.

DADDY: Precisely. What does it have to do with why what's- her- name is here? (87)

It is notable that Mommy is shown to be complaining about the beige hat as she insisted on the wheat one and then she returned to the shop and replaced it with the beige one, the colour she wanted it in the first place. However, it is revealed that the seller had sold her the same hat. When Daddy proposes that the seller had tricked her as he gave her the same hat, she answers, "well, yes of course, it was, you can't get satisfaction, just try . . . I can get satisfaction."'(63)

This is a proper illustration of an absurd conversation, Mommy tells Mrs. Barker that, "you have a hat just like the one I bought yesterday" and Mrs. Barker responds with a little laugh, "No, not really; this hat is cream" (79) Though Mommy was aware that the shop salesman had deceived her, the way of accepting the same hat again indicates her yearn to practice her personality's potency and her female independence; she pleases her violent desire to dominate her environment. Michael E. Rutenberg, writes that "Mommy is the consummate 'bad mother'; sadistic, jealous, greedy and onward. At the same level, the play leaves the spectator 
enthralled with Mommy's sadism; the effect it generates is one of a masochistic submission to her violence."'(231)

It is noteworthy that the play commences with Mommy talking discussing about her shopping and mimicking her club chairwoman. She is powerfully dominant in her house especially with her husband. This justifies the lack of the respect, understanding, love, self sacrifice. The marriage of Mommy and Daddy is apparently seen as an indication of the American deteriorated model of the life, which is part of the general fiasco associated with the American culture.

This play is a prophetic visionary piece, as it mirrors the decline of the American maternal institution not only during the time it was written, but it seems to widens, through its insights, beyond the contexts of the time it was written. Wendell Harris in Critical Essays on Edward Albee believes that, "although the text locates itself clearly in the 1960's . . . much of the play's message feels even more current in the cynical and disillusioned 1990's than it might have been when the play premiered in the more optimistic American world of 1961."’(112)

Hence Mommy is the suitable label for the selfish American female. Grandma addresses the audience that Mommy's aim was to marry for money not for love; Daddy was chosen for being wealthy. Grandma further relates that Mommy materialistic nature was discovered when she was only eight years old: "When I gwo up, I'm going to mahwy a wich old man . . . that's what I'm going to do." Furthermore, when Grandma leaves to purchase more boxes, Mommy reveals her intense craving for possession; selfishness governs her relationship with Daddy: "you can't live off people . I can live off you because I married you . . I have a right to live off you because I married you ... and I have a right to all your money when you die." (67)

From a feminist viewpoint, social relations are established and regulated in the gender- graded spatial division of public and private spheres: women's mobility and roles are confined to the private sphere; whereas men often regard the public sphere, the work place and the community, as their main space for activity. Such segregation of space consigns woman's role to mother, wife, and daughter and their living in the home area in which men own the house and the family as their own property. Home is the place product of spatial control over gender hierarchy. Men return from their work to home for rest and service by women, yet women do the housework from which they are never free. Thus home becomes the area for the feminist argumentation devoted to the liberated women from oppressive housework and gender role.

However the home is not a static building with animate and inanimate subjects, but a space of contingent convergence of multiple networks of social relations, among them, gender and age relations. When Doreen Massey in Space, Place and Gender attempts to elaborate how social relations are articulated in terms of spatial relations, she argues that, "space should be conceptualized integrally with time" (2) With Massey's highlight of the contingency, mobility and multiplicity of conceptualizing spatial relations in terms of time, the juxtaposition of space and time in gender issue implicitly discloses another significant element in considering how gender identity is maintained in spatial practice : age. When time goes by, gender role and spatial territory at home may be redistributed and boundaries may be re-established due to the mobility, addition or reduction of family members. Therefore when discussing gender as a category culturally constructed and yet apt to change through time, it is essential to involve age as a crucial factor based on social hierarchy in a capitalist industrialized society which stresses work competence and achievement.

As soon as Mommy asks Mrs. Barker the reason for her visit, she replies that she forgets why she has called; Grandma tries to remind her by hinting about a visit made in the past. Grandma refers to a story as mentioned earlier in this chapter, about a married couple who invited a representative of the Bye-Bye adoption service to adopt a "Bumble of Joy" or baby. Due to their impotence, they attempt to produce a symbol of fertility in their life; one elucidation of this story is the inborn barrenness of this couple and the mendaciousness of the productivity of the American family. According to Albee the conjugal unfruitfulness is the contradictory theme to the myth of the American fertility. The reference made by Grandma to the couple in the story as "a man very much like Daddy, and a woman very much like Mommy" and a "dear lady" similar to Mrs. Barker. Gerald Weales in Edward Albee: A Collection of Critical Essays points out that "everything in The American Dream is not original but fake; Mommy confuses illusion to reality; in Mommy's words, 'a great deal like it'. Like it, but not it. Appearance is what she wants for reality is dangerous."(16)

As a result Grandma is more prepared to accept living under the light of reality. She is the only one in the family who is aware of the past; a past when America was still fertile and productive with well constructed social and spiritual values. Grandma's symbolization with America becomes more obvious when she reveals that she was once married to a farmer; this fact connotes all the benevolent virtues of the rural America embodied in Grandma who has led a happy life away from the city. Mommy despises her by saying "she is rural". Addressing the audience, Grandma can be seen as a metaphysical or a fugitive figure that moves freely in and out of the context of the events of the play.

Before the ending of the play, Grandma discovers a character, the Young Man as being the American Dream. Grandma observed the time before the materialistic spirit subjugated the virgin land; she stands for the 
old virtues and good times. The disparity between the young beautiful virgin that Grandma was once and today's old senile "Grandma" is called to mind due to the meeting between her and the Young Man. He astounds everybody with his physical skills as when Grandma notices him for the first time. She cries out: "Yup ... Yup. You know, if I were about a hundred and fifty years younger I could go for you.”(106)

The connection between Grandma and the American Adam becomes even more organically patent after the encounter with the Young Man. Though Grandma's gender as a female may enforce a hindrance in considering her as a substitute of the American Adam, yet she says previously in the play: "I look just as much like an old man as I do like an old woman." (111)

It is similar with Eugene O'Neill's The Strange Interlude where Nina's second son comes to substitute her previously devastated dream of being a mother. In the play The American Dream, a new character appears; a young man, to replace the previously adopted child and later it became the representative of the American Dream.

The only point about the young man that comes into consideration is his appearance. Grandma is stunned by his young good looks and masculinity.

GRANDMA: I said, my, my, aren't you something.

YOUNG MAN: Oh. Thank you.

GRANDMA: You don't sound very enthusiastic.

YOUNG MAN: Oh, I'm ... I'm used to it.

GRANDMA: Yup ... Yup. You know if I were about a hundred and fifty years younger I could go for you.

YOUNG MAN: Yes, I imagine so.

GRANDMA: Unh-unh ... will you look at those muscles!

YOUNG MAN: (Flexing his muscles) Yes, they're quite good, aren't they?

GRANDMA: Boy, they sure are. They natural?

YOUNG MAN: Well the basic structure was there, but I've done some work, too ... you know, in a gym.

GRANDMA: I'll bet you have. You ought to be in the movies, boy

GRANDMA: Oh, that's nice. And will you look at that face !

YOUNG MAN: Yes, it's quite good, isn't it? Clean-cut, midwest farm boy type, almost insultingly good-looking in a typically American way.

Good profile, straight nose, honest eyes, wonderful smile (106)

As mentioned earlier that Grandma is the first one to get acquainted with the young man, she is also the first person to note something well-known in the young man's exterior. It seems palpable that this familiarity has great importance in the play, it is not just accidental; the young man comes back as a survivor from the past. GRANDMA: Hey! You look familiar.

YOUNG MAN: Hm? Pardon?

GRANDMA: I said, you look familiar.

YOUNG MAN: Well, I've done some modeling.

GRANDMA: No ... no. I don't mean that. You look familiar. (112)

After identifying all the young man's physical traits and familiarity he expresses, it is obvious that Grandma cannot reflect on anything else besides watching the young man as the personification of the "American Dream". The young man is seen as the prototype of what any American family would expect from a son and therefore the positive side of the Bumble is referred here.

GRANDMA: Yup. Boy, you know what you are don't you? You're the American

Dream, that's what you are. All those other people, they don't

know what they're talking about. You ... . you are the American

Dream. (108)

If on one hand the Young Man is introduced as the prototype of the "American Dream" man for his physical qualities, on the other hand he feels he is not a complete being.

YOUNG MAN: No, no. It's part of the interviews. I'll be happy to tell you. It's

that I have no talents at all, except what you see ... my person,

my body, my face. In every other way I am incomplete, and I

must therefore ... compensate. (113)

As a result, the American Dream Man, who has come to restore the damaged and consequently murdered child, seems to be a dream or a parody of the American Man. R.W.G Lewis has explained the concept of the New World Hero in the American Adam in W. Guerin A Handbook of Critical Approaches:

a radically new personality, the hero of the new adventure: an individual emancipated from history, happily bereft of ancestry, untouched and undefiled by the usual inheritances of family and race; an individual standing 
alone, self-reliant and self-propelling, ready to confront whatever awaited him with the aid of his own unique and inherent resources. (145)

Lewis has also pointed out that the American Adam would also serve as the central figure of the Dream of success, the Self-Made-Man who is free from materialism and possesses a sense of humanity, hence the archetype of the American hero.

Grandma becomes the central character in the play as she begins to practice the authority of telling the truth about each character including her. As she is aware with the history of her family Grandma narrates to Mrs. Barker what happened to the "Bumble of Joy" who is actually the twin brother of the Young Man. During his childhood the "Bumble of Joy" acted naturally; he was full of vigor and vitality; he bawled in front of Mommy, undermining her hostile nature with his unprompted reactions. He replied negatively against all the artificiality of behavior that he received from Mommy and Daddy. They believed that being natural should not pass without punishment, without cutting the down the source of that annoyance. Hence the baby went through a gradual procedure of disfigurement. Slowly all his organs were dismembered, his eyes were taken out, he was castrated, and even the hands were cut off. Grandma comments "Well, it finally died; and you can imagine how those made them feel, their having paid for it and all."'(78)

After assassinating the baby what Mommy and Daddy cared for was how to get their money back; they thought they were double-crossed as the child's nature was opposite to their own will and that he finally did not appeal to them and this was the motive behind his death. They killed the human potential in him; the impulsiveness and creativity. Brain Way writes that:

Albee has given us a fable of his society, where all the capabilities for connection eyes- to see, sexual organs, with which victim of the socializing way of the American way of life, humanly speaking, dies. (36)

The implication of the child's dismemberment is fully realized after the recognition of Grandma with the Young man as the American Dream. He is identified by Grandma with this name as the quintessence of all hopes and expectations of the American people. He narrates to Grandma what he was going through at different times in his childhood. First, when he was separated from his twin brother. He began to feel that the most important bonds that he shared with himself and the people around him were harshly severed: "I have suffered losses . . . that I can't explain. A fall from grace . . . a departure of innocence . . loss . . loss" (115)

The "fall from grace" entails a strong nostalgic yearning to stick to the idea of Eden or "innocence" before the fall. The actual fall from the grace of being human is a clear demonstration of the spiritual death of the Young Man who stands for the culture of the whole nation. Martin Esslin in The Theatre of the Absurd believes that the play fundamentally hits the "sentimental ideals of family life, togetherness . . . and unwillingness to face the ultimate facts of the human condition that in America . . represent the essence of bourgeois assumptions and attitudes." (24)

Disemboweled as he is, the Young Man becomes sensitively detached from the outer world as he begins suffering bizarre spasms of pain consequently losing his soul, and hence he is spiritually dead. He tells Grandma that since that time he could hardly feel anything towards anyone around him but, "cool disinterest ... I have no emotion ... I have, now, only my person

.. . my body, my face . . . I am incomplete .. . I can feel nothing." (115)

Spiritually dead, the Young Man searches for the substitution to that loss, though materialistic. He finds out, that money is the replacement and hence his ultimate aim; paradise is no longer bound to the past. The present illusion promises a better earthly Eden of lust and possession. Thus, ready to do anything for money, the Young Man trades his physical perfection for social responsibility. He becomes a shell, empty of any human feeling boasting no talents except what he looks like. He describes himself as "clean-cut, Midwest farm boy type, almost insultingly good-looking in a typically American way ..." (107)

The Young Man has no family to speak of, and he misses his twin brother. A sense of incompleteness and loss had always disturbed him after he and his identical twin, two halves of the same egg and the same being, "were torn apart . . . thrown to opposite sides of the continent," when still very young. Their lives had faced hardships and seclusion from the beginning, with an unknown father and a dying mother on the night of their birth. If this youth has the looks, the charms and the goal to grow rich, victorious and famous, but is short of the innocence, sentiment and love, question arises whether the other twin brother symbolizes the moral and noble side of the American Dream? One may wonder if the Other Half, who vanished and may be dead, carried moral values that could not survive the suffocating aggression and the consumerism of the modern times.

The Young Man apparently found a job as a suitable dubious entertainment figure. He is paid to give satisfaction to the hollow lives of a middle class couple comprising of Mommy and Daddy, a parody picture of the common family and the average community. They embody some usual bourgeois qualities: the concern with the distinguishing appearance, the general expectation of the male superiority; the idea of masculinity associated with decisiveness, power and money; the emphasis on ambition and gaining; the absence of love; the commercialized relationships; the general emptiness and sterility even as 'satisfaction' is presented as supreme goal. The inability of Mommy and Daddy to bear children adds a grave edging and points to powerlessness and 
decay. Some references to one imperfect child, once adopted, paid for and now dead spring up in the conversation. Mommy and Daddy had only wanted "a bumble of joy" and were disappointed with the child they had brought in the past. But the Young Man now seems what they just needed- their dream come true.

In the closing scene, Grandma plans with Mrs. Parker to adopt the American Dream Mommy and Daddy, who seems to be excited to the idea. Hence here Grandma leaves the stage with a box of eighty-six years of life, a symbolic exit of all rural virtues, which were once in survival and guidance of the American way of life. The Young Man is the result of a murder. What eventually came out of the Bumble of Joy are disfigured bits and pieces of a natural baby. The Young Man is referred 'familiar' twice by Grandma; a close metaphysical relationship between the two is seen.

The relationship seems more than just a physical connection of a warm memory. Albee associates Grandma with a mythical significance symbolically when she first examines the Young Man and immediately identifies him as The American Dream; the title of the play is organically based on this fact.

The detailed description of the Young Man's mount up feelings of losing his parts of humanity clears many doubts about Daddy's powerless nature. At the same time, as "Bumble of Joy" was going through mutilation, Daddy was morally and physically losing the same parts. Daddy himself hints to this when he gives reference about the surgery he had and ignorance of what the doctors had put in his body: "the doctors took out something that was there and put in something that wasn't there." (86)

The Young Man in return, corresponds with a related feeling of the above mentioned deadening experience. As Mommy asks him about the ringing of the bell, Grandma's reply is almost comical: "The American Dream! ... The American Dream! Damn it!" (108)

It is the epiphany imagined by Grandma, the synthesis of the timeline, a confrontation between an innocent vision and a mutilated shell. The two poles of human nature, good and evil, could not meet; so one of them should take over. When the Young Man attempts to speak to Grandma by coming closer, she exclaims, "Stay there! Don't come any closer ... I might faint." (110)

Grandma departs the stage after her replacement with the Young Man; Mommy is contended with her fulfilled dream. Off stage, Grandma draws down the curtain saying, "Lets leave things as they are now ... while everybody got what he wants ... or everybody's got what he thinks he wants ..." In the end the eviscerated Young Man takes up Grandma's room in the house. As Mommy moves closer to the Young Man she informs him that he will learn about a few things "may be . . . may be later tonight." (127)

As a result the Young Man, described in this play, is only a dream because, in addition to his physical qualities, he is described as a flawed being; hence the contrary of what originates from the Edenic mythological figure of the American Adam. The Young Man symbolizes a character that is near to the American nightmare than the American Dream as he himself admits that he consists only of muscles and a strong exterior, but lifeless inside, worn out of genuine feelings. Besides he will achieve anything for money.

Therefore, as the Young Man starts to disclose about himself, all the facts connected with his feelings of incompleteness can be associated to the Bumble's maiming. If the Bumble was once physically disfigured till nothing was left, the Young Man has a similar feeling that nothing, except his good looks, are left. He has also surrendered as the Bumble did once in the past. The Bumble has been his twin brother, as the text indicates:

YOUNG MAN: We were identical twins ... he and I . . not fraternal ...

identical, we were derived from the same ovum; and in this, in

what we were twins not from separate ova but from the same

one, we had a kinship such as you cannot imagine. (114)

All the things that were done to his twin brother have also affected him. Thus since everything that the Young Man reveals to Grandma regarding his moral defects has its association with the physical injuries that his twin brother had suffered from Mommy and Daddy.

Bumble lacked heart due to the physical injuries that he received from Mommy and Daddy, "One night it cried its heart out" (99) the Young Man lacked love, "Once ... it was as if all at once my heart became numb . .. and from that time I have been unable to love." (115) Bumble lost his eyes by the physical injuries caused by Mommy and Daddy, "Why, any self-respecting woman would have gouged those eyes right out of its head"(99) and the Young Man lacked the ability to see affection, "Once ... I was asleep at the time I awoke and my eyes were burning. And since that time I have been unable to see anything, anything with pity, with affection ... . with anything but. . . cool disinterest." (115) Bumble was castrated, "But then, it began to develop an interest in its you-know-what" (99), the Young Man lost the capability of having physical relation. Bumble lost his hands as they were cut off by Mommy and Daddy, "Well! I hope they cut its hands off at the wrists. Well, yes, they did that eventually" (99) and the Young Man had lost the power of touching and feeling, "And even my hands .. . I cannot touch another person and feel love." (115) And eventually Bumble suffered physical death by both Mommy and Daddy, "They cut its tongue out! . . . it didn't have a head on its shoulders, it had no guts, it was spineless, its feet were made of clay, it finally up and died" (99), similarly the Young Man suffered spiritual death as told by him, "And there is more ... there are more losses, but it all comes down to this; I no longer 
have the capacity to feel anything. I have no emotions. I have been drained, torn asunder disemboweled. I have, now, only my person ... my body, my face." (115)

The result of all this mutilation is demise, either physical in the Bumble or spiritual in the Young Man. Therefore, everything that was physically injured in the adoptive child is now lacking in the young man's inner self. In a way to pay off for all that has been taken away from him, he allows people to use everything he has; he allows people to love him but he cannot love them back, he allows people to touch him but he cannot touch back, he lets them draw pleasure from his groin but he cannot feel anything. Eventually it is only the Young Man finishes to narrating the story of his life Grandma; she realizes the relationships between the adoptive child and the new coming Young Man. Or even more than that: she seems to notice that the rejected child has now become the Young Man who is being worshipped as the American Adam.

GRANDMA: I was mistaken . . . before. I don't know you from somewhere, but I

knew ... once ... someone very much like you ... or, very much as perhaps you were. (115)

So, once the Young Man is presented as having the same faults as the Bumble did, what actually happens is that through the characters, Edward Albee is speaking ironically about the mythological figure of the American Hero; he is making a parody, through the Young Man's materialism and lack of moral virtues, of the uncorrupted Adam. For, as it has been observed, the Bumble has been killed for it did not achieve the ideals of perfection the parents wanted for a son, and now the Young Man is seen as possessing the same imperfections as the Bumble did, notwithstanding he is ironically worshipped as the American Dream.

MOMMY: (Herself again, circling the young man, feeling his arm, poking him).

Yes, sir! Yes, sirree! Now this is more like it. Now this is a great deal

more like it! Daddy! Come. see. Come see if this isn't a great deal more like it. (124)

As in Strange Interlude, The American Dream also presents a substitute for the child who went wrong and died; it is the Young Man who ironically represents the embodiment of the American Hero, therefore the materialism of his parents aspirations of what a son should look like.

In his preface to the play, Albee writes, "The play is an examination of the American scene, an attack on the substitution of artificial for real values in our society." (54) Grandma in the end refers to the contended life that Mommy and Daddy live; a life in denial and a life dream reduced to a myth from the past. Grandma that no longer exists is substituted by a pathetic figure called "The American Dream". At the end of the preface, Albee says, "I hope that The American Dream ... transcends the personal and the private, and has something to do with the anguish of us all." (54)

This work is definitely a satire where Albee is definitely drawing parallels to his life and the expectations of his parents especially his mother Frances who wanted to fit Albee into her social circle. She probably represents Mommy on whom as a character Albee has been extremely harsh. Mommy's pursuit of a perfect dream child probably represents Francis aspirations for Albee and he compares his disappointment as being destroyed like Bumble the adopted child. The satire also extended to the repressive consumerist American society which felt that their money could buy anything. It basically mocks the tendency of people in America substituting human values with a chronic obsession for material goods. Consumer goods are slowly taking precedent over family values as a poison spreading in all Consumer Capitalist Societies.

Ultimately, it is important to say that even though in this play infanticide can be considered metaphorical, there is still a reason behind it. For, unlike the previous works had predominantly negative themes like greed and shame, here the child's apparently normal traits lead both father and mother kill him in a horrid manner just because it did not satisfy them.

In Albee's The American Dream, the adoptive child represents the mythological figure of the scapegoat in the sense that it has been mutilated and killed so that the parents can reach the ideal family life they are pursuing. It is a life which seems to be threatened by the physically imperfect child. Thus, the baby passes through a shocking treatment of mutilation, which concludes to its death, in order to atone for its imperfections which are ultimately the parents own deficiencies. Mommy and Daddy have transferred all their imperfections to the child. The child thus becomes a scapegoat. They think they can achieve the ideals of physical fitness in the family through another and more acceptable son. Hence in this way, the examined motives which are apparent in this play, as the disintegration of the ideal family life, the search of the uncorrupted Adam, bringing myth and the tradition of the Absurd together, lead Mommy and Daddy to kill the child for it represents neither the ideal of family nor the American Adam.

\section{Conclusion}

This infanticide which is imaginary and the projection of the self-centered consumer oriented thought of an American nuclear family. The infanticide may not take place in reality but the dismemberment and eventual death of Bumble signifies as per Albee the ills of Post War American materialism. 
The present world consists of this worldly race for consumer toys actually committing infanticide by judging their children by commercial standards which when not met cause parts of our progeny slowly dying. This is more of a psychological projection of infanticide which kills the mental well- being of our children portion by portion. The children eventually end up becoming the emotionless, feeling less American Dream killed by so called modern expectations of the parent of the child.

\section{References:}

[1] Albee, Edward. The American Dream and The Zoo Story. Signet: New American Library.1959. Print.

[2] Barnett. S. A Short Guide to Writing about Literature. 2 ed. Boston, Little, Brown, 1971. Print.

[3] Baxandall, Lee. "The Theatre of Edward Albee" The Modern American Theatre: A Collection of Essays. Ed Alvin B. Kernan. Englewood Cliffs, NJ: Prentice Hall, 1967

[4] Canaday, Nicholas, Albee's The American Dream and the Existential Vacuum, London : South Central Bulletin. 1966. Print.

[5] Esslin, Martin. The Theatre of Absurd. New York, Penguin Books. 1968. Print.

[6] Guerin. W. et al. A Handbook of Critical Approaches to Literature. New York. Harper and Row, 1966. Print.

[7] Harris, Wendell V. "Morality, Absurdity and Albee" Critical Essays on Edward Albee. Philip C. Kolin and J. Madison Davis. Boston, Massachusetts G.K Hall and Co.1986. Print.

[8] Jacques, Damien. A Discussion Of Modern American Drama: Edward Albee, Milwauki Journal Sentinal, 2002. Print.

[9] Massey, Loreen, Space, Place and Gender. Minneapolis: University of Minnesota Press.1994. Print

[10] O’Neill, Eugene. Three Plays. New York, Vintage Books, 1959. Print.

[11] Rutenberg, Michael. "Albee in Protest". Critical Essays on Edward Albee. Philip C. Kolin and J. Madison Davis. Boston, Massachusetts: G.K Hall and Co. 1986. Print.

[12] Spiller, E. Robert. An Introduction to the American Literature, New York: The MacMillan Company.1966. Print

[13] Way, Brian. "Albee and the Absurd: The American Dream and The Zoo Story" in Edward Albee: A Collection of Critical Essays, Philip C. Kolin and J. Madison Davis. Boston, Massachusetts G.K Hall and Co.1986. Print.

[14] Weales, Gerard. "Edward Albee: Don't Make Waves", Edward Albee: A Collection of Critical Essays, ed. New Jersey: Prentice Hall, Inc, Englewood Cliffs , 1975. Print. 